\title{
Regulating Water Quality: Current Legislation, Future Impacts: Introduction to the Colloquium
}

\author{
Sarah A. White ${ }^{1}$ \\ School of Agricultural, Forest, and Environmental Sciences, Clemson University, E-143 P\&AS, \\ Clemson, SC 29634-0310
}

\begin{abstract}
Additional index words. Chesapeake Bay, Clean Water Act, floating treatment wetlands, nitrogen, numeric nutrient criteria, nursery crop production, pesticides, phosphorus, sediment, sub-surface flow wetlands, surface-flow wetlands, water sampling
\end{abstract}

Increased rates of nutrient enrichment in surface water bodies have led to detrimental impacts to aquatic ecosystems; these impacts include algal blooms, fish kills, and dead zones. Environmental groups and concerned citizens have begun to demand greater protection and restoration of our natural waterways, because both human and ecological uses are currently impaired as a result of increased rates of nutrient and sediment loading. Many policies have been enacted in regions throughout the United States to reduce nutrient loading with the ultimate goal of improving surface water quality and restoring ecological function (e.g., fisheries, native plant communities) [U.S. Environmental Protection Agency (EPA), 2010a, 2010b, 2012].

Concern for aquatic ecosystem health has led to federal enforcement of the EPA Clean Water Action Plan in two current cases, which include: the numeric nutrient criterion imposed on surface waters in Florida and the Chesapeake Bay consent decree where total maximum daily loads were imposed to reduce nutrient loading into surface waters (U.S. EPA, 1998, 2010a, 2010b). These nutrient load reduction mandates impact all sectors of society, including industrial, urban, and agricultural water users, because wastewater from all of these land use types contribute to the overall load of nutrients within an ecosystem, regardless of whether the wastewater is considered to be from a point source or a nonpoint source.

Many horticultural crop producers are being impacted in Florida and the Chesapeake Bay watershed (Delaware, the District of Columbia, Maryland, New York, Pennsylvania, Virginia, and West Virginia); these states are currently implementing changes in practice or evaluating potential changes to moderate the amount of nitrogen $(\mathrm{N})$, phosphorus $(\mathrm{P})$, and sediment in wastewater leaving farms.

Received for publication 27 Feb. 2013. Accepted for publication 19 Mar. 2013.

Special thanks to Drs. John Lea-Cox and Don Merhaut for their critical review of an earlier draft of the manuscript.

This paper was part of the colloquium "Regulating Water Quality: Current Legislation, Future Impacts" held 1 Aug. 2012 at the ASHS Conference, Miami, FL, and sponsored by the Nursery Crops, Water Utilization and Management, Waste Utilization in Horticulture, and Floriculture Working Group. ${ }^{1}$ To whom reprint requests should be addressed; e-mail swhite4@clemson.edu.
Additional nutrient regulations will likely impact additional horticultural crop producers throughout the United States over the next decade, because degrading surface water quality is a national issue. Without an adequate understanding of the complex issues surrounding agricultural water use and reuse, scientists, policymakers, and extension specialists alike will not be able to address the multifaceted management problems that horticultural crop producers are likely to face in the coming years. In light of these complex issues and the need for open discourse among these groups, the American Society for Horticultural Science Nursery Crops working group convened a colloquium entitled " Regulating Water Quality: Current Legislation, Future Impacts," cosponsored with the Water Utilization and Management, Waste Utilization in Horticulture, and Floriculture working groups to educate attendees regarding 1) the current state of nutrient-based legislation; 2) the impact of Florida Department of Environmental Quality imposed numeric nutrient criterion on growers' changing practices in Florida; and 3) the remediation technologies available for growers' compliance with mandated nutrient and sediment limits for runoff from production areas.

\section{THE COLLOQUIUM}

The three articles in this series discuss the current regulatory climate, the impact of regulations on managing water quality, and the remediation technologies currently available to cleanse wastewater of nutrient and sediment contaminants. Four colloquium speakers, Steve Beeman (Beeman's Nursery), Pete Spyke (Arapaho Citrus Management, Inc.), Aliso Coe (EarthJustice), and Dr. P. Christopher Wilson (University of Florida), declined the opportunity to submit articles. An overview of the presentations is discussed in the order presented during the colloquium.

\section{A BRIEF HISTORY OF REGULATORY ACTIONS}

Majsztrik and Lea-Cox (2013) present a brief history of the legislative actions taken to restore the Chesapeake Bay that culminated with introduction of federally mandated total maximum daily load limits in 2010 (U.S. EPA, 2010a) and current efforts to accelerate implementation of best management practices.
The need for increased communication among regulatory agencies, policymakers, modelers, and stakeholders is discussed with regard to managing and accurately accounting for changes in nonpoint source contributions to the watershed. This article specifically emphasizes efforts to accurately characterize current nursery and greenhouse inputs, the potential affect of altering production practices, and implementing best management practices to reductions of nutrient and sediment contaminants in the Chesapeake Bay. The value and longevity of nutrient trading credits are discussed along with pitfalls and benefits for growers.

Alisa Coe, an Associate Attorney with the Tallahassee Office of Earthjustice, a non-profit, public interest law organization, discussed the role of political activism in impacting policy change. In 2008, a coalition of environmental organizations represented by Earthjustice filed a lawsuit against the U.S. EPA for failing to comply with its nondiscretionary duty to set numeric nutrient criterion for Florida as mandated by the 1972 Clean Water Act and the 1998 Clean Water Action Plan (Douglas, 2012; Stanton and Taylor, 2012). The depth of problems created by unmitigated nutrient runoff into surface waters included human health, ecological sustainability, and economic concerns. Human health concerns were related to drinking water contamination and dermal or inhalation contact with algae that secrete/ excrete toxins. Environmental and ecosystem health concerns were related to habitat loss and fish kills from low dissolved oxygen. Economic concerns were related to decreased property values and declining tourism in some regions of Florida where waterways are detrimentally impacted by algal blooms. These issues were the motivating factors for the "Clean Water Act Citizen Suit."

The foundational argument for the Clean Water Act Citizen Suit was that the Florida Department of Environmental Protection (FL DEP) had not developed numeric limits for sewage, fertilizer, and manure pollution 9 years after the Clean Water Action Plan was enacted. Thus, the U.S. EPA should enforce nutrient criterion in water bodies in Florida rather than the FL DEP. In January 2009, the EPA made a determination that Florida's narrative standards were ineffective and numeric nutrient criteria were, in fact, needed for Florida's water bodies. In Aug. 2009, the litigation was settled with a consent decree requiring development of specific or "numeric" 
nutrient pollution standards by Nov. 2010 (U.S. EPA, 2010b). In response, the FL DEP proposed limits for $\mathrm{N}$ and $\mathrm{P}$ in dark tannin lakes, clear lakes, streams, springs, and water watershed regions. The proposed numeric criterion was adopted and then challenged in U.S. District Court for the Northern District of Florida. In Feb. 2012, a federal judge offered a mixed ruling on criteria for Florida nutrient standards, upholding criteria for lakes and springs but invalidating criteria for streams as "arbitrary and capricious." In Nov. 2012, the U.S. EPA approved state numeric nutrient criteria for concentrations of $\mathrm{N}$ and $\mathrm{P}$ allowed in Florida's waterways (U.S. EPA, 2012). Agricultural producers can maintain a presumption of compliance with these approved numeric criteria by enrolling in the Florida Department of Agriculture and Consumer Services Best Management Practices (BMPs) Program and by implementing approved BMPs (Florida Department of Agriculture and Consumer Services Office of Agricultural Water Policy, 2011).

\section{COMPLIANCE EFFORTS}

Merhaut et al. (2013) discuss the current regulations and the educational programs that were used to help the agricultural sector mitigate nutrient and pesticide runoff in specific watersheds in southern California and the monitoring protocols that were used to measure changes in runoff water quality in these particular watersheds. They focused on specific educational programs that have been developed to educate growers about BMPs that mitigate pesticide and nutrient runoff from specific production sites and the monitoring protocols used to verify the efficacy of grower adoption of BMP practices. Steve Beeman, owner of Beeman's Nursery in New Smyrna Beach, FL, discussed the use of floating treatment wetlands (Beemats) to improve water quality by limiting growth of aquatic weeds such as duckweed and algae. Beemats improve water quality in stormwater ponds, canals leading into stormwater treatment areas, and nursery retention ponds. Pete Spyke, of Arapaho Citrus Management, Inc., discussed use of open field hydroponics, an advanced citrus production system that incorporates drip irrigation, fertigation, and pulsed irrigation events to grow vigorous citrus groves that yield earlier while limiting loss of water and nutrients through enhanced irrigation management. Christopher Wilson presented results of research conducted with bacterialbased bioreactors to reduce high concentrations of nitrate from production runoff. Wilson also explored differences in leaching rates and subsequent remediation efficacy as influenced by changing the $\mathrm{N}$ source from soluble $\mathrm{N}$ to a controlled-release $\mathrm{N}$ source. White (2013) discusses the ecological impacts of nutrient enrichment of surface waters and the remediation principles that govern the efficacy by which constructed wetland technologies (surface flow, subsurface flow, and floating treatment wetlands) remove $\mathrm{N}$ and to some extent $\mathrm{P}$ from production runoff. White also details situational and practical concerns related to application of each wetland technology to cleanse nutrients from production effluent.

\section{CONCLUSIONS}

It is important to determine how we will protect our water resources so that both human and environmental services are maintained as competition for freshwater resources increases. Demands on fresh water will inevitably increase as a result of increasing urban, industrial, and agricultural use in support of population and economic growth (Zinati, 2011). We need to learn lessons from present regulatory actions that influence all agricultural producers, whether they produce agronomic, horticultural, or animal products. The ability to inform and influence future changes in production and BMPs is critical not only for the long-term viability of our production systems, but also for the sustainability of our ecosystems.

\section{Literature Cited}

Douglas, D. 2012. Federal court issues mixed ruling on criteria for Florida nutrient standards. Daily Environment Report ${ }^{\mathrm{TM}}$. 22 Feb. 2012. 17 Dec. 2012. <http://www.bna.com/federal-courtissues-n12884907984/>

Florida Department of Agriculture and Consumer Services Office of Agricultural Water Policy. 2011. TMDLs and agricultural BMPs. 20 Dec. 2012. <http://www.floridaagwaterpolicy.com/ PDF/Ag_Bmps_and_Florida_Tmdls.pdf $>$.

Majsztrik, J.C. and J.D. Lea-Cox. 2013. Water quality regulations in the Chesapeake Bay: Working to more precisely estimate nutrient loading rates and incentivize best management practices in the nursery and greenhouse industry. HortScience 48:1097-1102.

Merhaut, D.J., L. Corkidi, M. Mochizuki, S. Webb, and J. Newman. 2013. Implementation of best management practices to reduce agricultural TMDLs in the Calleguas Creek and Santa Clara River watersheds: A case study of water reclamation in California. HortScience 48:11091112.

Stanton, E.A. and M. Taylor. 2012. Valuing Florida's clean waters. Stockholm Environment Institute-U.S. Center.

U.S. Environmental Protection Agency. 2010a. Draft Chesapeake Bay total maximum daily load. Section 9. 19 Dec. 2012. <http://www.epa. gov/reg3wapd/tmdl/ChesapeakeBay/drafttmdlexec. html $>$.

U.S. Environmental Protection Agency. 2010b. Final water quality standards for the state of Florida's lakes and flowing waters. Office of Water. EPA-820-F-10-008.

U.S. Environmental Protection Agency. 2012. Multiple EPA Actions Related to Nutrient Pollution in Florida Waterways. U.S. Environmental Protection Agency, Office of Water. Watershed Events. EPA-820-F-12-053.

U.S. Environmental Protection Agency. 1998. President Clinton announces Clean Water Action Plan. U.S. Environmental Protection Agency, Office of Water. Watershed Events. 840-N-98-001.

White, S.A. 2013. Wetland technologies for nursery and greenhouse compliance with nutrient regulations. HortScience 48:1103-1108.

Zinati, G.M. 2011. Water management and plant performance in a changing climate: Introduction to colloquium. HortScience 46:152-154. 